ISSN : $2302-1590$

E-ISSN: $2460-190 \mathrm{X}$

Economica: Journal Of Economic And Economic Education

Volume 10, Issue 1, October 2021, pp 40-49

\title{
THE ANALYSIS OF INFLUENCED FACTORS ON GER IN SENIOR HIGH SCHOOL
}

\author{
Siska Ayu Octarina'), Suratno ${ }^{2)}$, Kuswanto $^{3)}$ \\ 1) Master of Economic Education Study Program, Jambi University, Indonesia \\ Email: octarina291091@gmail.com \\ 2) Master of Economic Education Study Program, Jambi University, Indonesia \\ Email: suratno@unja.ac.id \\ ${ }^{3)}$ Master of Economic Education Study Program, Jambi University, Indonesia \\ Email: kuswanto.fkip@unja.ac.id \\ Submitted: 2021.05.31 Reviewed: 2021.10.19 Accepted: 2021.10.28 \\ https://doi.org/10.22202/economica.2021.v10.i1.5340
}

\begin{abstract}
The Gross Enrollment Rate (GER) is one of the indicators used to see the level of education participation in Indonesia. One of the main focuses of this research is the low Gross Enrollment Rate (GER) for high school education in Indonesia. This is very clearly seen when compared to the other two levels of education. This study aims to examine and analyze the factors that affect the GER for high school / equivalent education in Indonesia in 2015-2019. The method used in this research is the quantitative method. The type of data used is secondary data from the National Statistics Agency (BPS). While the analysis technique used is a panel data regression model that combines cross-section data and time-series data. Where the cross-section data used covers 34 provinces in Indonesia, while the time series data used are from 2015-2019. The analysis in this study was carried out using the help of Microsoft Excel 2010 and Eviews 10. The results of the study found that partially poverty, student-to-teacher ratios, and per capita GRDP affected GER, while the number of education units (schools) had no effect at all. Another case with simultaneous testing results in all variables influencing GER.
\end{abstract}

Jel Clasification:

I200;I210;I300

Keywords: Gross Enrollment Rate, SMA, Student to Teacher Ratio, Poverty, GRDP per Capita

(C2021 Economic Education Study Program STKIP PGRI West Sumatra, Indonesia 


\section{INTRODUCTION}

One of the characteristics of a developed country is having human resources (HR) with quality, superiority, competitiveness, and character. Quality human resources will be able to bring a country to achieve a goal and change for the better in various fields. Human resources are closely related to the education of a nation. Education is an important key in creating quality human resources. The quality of Human Resources (HR) in society can be measured by the level of education completed, the more highly educated people show a better quality of society (Istiqomah et al., 2018). Therefore, the low quality of a nation's education will also affect the quality of its human resources.

Education is one of the top priorities in the national development agenda that has been set by the government in the 2015-2019 National Medium Term Development Plan (RPJMN 2015-2019). One of the goals to be achieved is the implementation of the Smart Indonesia Program (PIP) through the implementation of the 12-year compulsory education so that it can increase the enrollment rate for primary and secondary education. In the 2015-2019 National Mid-Term Development Plan (RPJMN 2015-2019) it is stated that the GER target for high school education / national equivalent in 2019 is 91.6 percent. This, of course, is quite heavy homework considering that in 2019 the national GER is still far from the expected target, which has only reached 83.98 percent.

According to data published by the National Statistics Agency (BPS, 2020) in 2015-2019, the high school/equivalent education level is the level of education that always provides the lowest percentage of GER each year compared to primary school education/equivalent and Junior High School/equivalent levels. Based on these data, the percentage of GER at the level of elementary school education or equivalent from 2015-2019 always touches more than 100 percent, while the level of junior high school education/equivalent is always in the range of 90 percent. For the highest achievement at the level of primary school/equivalent education itself was in 2015 which reached 110.5 percent. Meanwhile, junior high/equivalent education has the highest percentage of GER in 2018, which is 91.52 percent. It can be seen that there has been a vast disparity with the percentage of GER achieved by the high school/equivalent education level which is only able to provide the highest percentage of only around 83.98 percent in 2019 . The percentage of GER for high school/equivalent education level in 2019 is 83, 98 percent can even be said to be very far from the expected national target of 91.6 percent.

One of the main factors affecting the low GER achievement in an area is the problem of poverty. The impact of the poverty problem that has never been resolved is that many children from poor households find it difficult to access educational facilities, which in turn makes them fall even further into underdevelopment and underdevelopment. As a result of poverty, the population has limited access to education, which causes the low quality of human resources which results in low productivity and low income received (Jonaidi, 2012). Whereas in fact, higher education will be able to change and raise the level of a person's life. With a good education, everyone will be equipped with skills and abilities (competencies), have many choices in work, become more productive so that they can increase income, break the poverty chain, and eliminate social exclusion to improve the quality and welfare of their lives (Ustama, 2009).

Another factor that contributes to the low achievement of educational participation in an area is the number of education units (schools). According to (Pramudibyanto and Weningsih, 2018) one of the demand factors that can affect the enrollment rate is the number of schools. The minimal number of schools will make the school limit registration for prospective students so that many children cannot study or are forced to look for other schools that have further distance. School distances that are far will make a lot of considerations for parents to send their children to school. Among them are additional transportation costs (if you go back), the cost 
of renting a house or boarding house for those who are not possible to go back and forth, and the safety issue of children.

Apart from the number of education units (schools), another factor that also influences the achievement of educational participation is the ratio between students and teachers. If the number of students is not commensurate with the number of teachers who will teach, then this will make the school adjust its capacity to capacity to maintain the quality of the learning process. This of course will have an impact on decreasing the GER. Apart from that, the per capita GRDP is also quite influential in increasing the GER in a region. The amount of per capita GRDP also greatly influences a person's decision in choosing to pursue education. Because the greater the income received by a person, the more influential it will be to increase the welfare of that person. So that it will be very helpful in increasing education participation, especially the Gross Enrollment Rate (GER).

This study is in line with research conducted by (Khairunnisa et al. 2014; Rahmatin dan Soejoto, 2017; Listianawati, 2012) who use poverty, the number of education units, student to teacher ratios, and per capita GRDP as independent variables. However, there are differences in the period, research scale, educational indicators, and level of education. This study aims to examine and analyze comprehensively to see whether poverty, the number of education units (schools), student to teacher ratios and GRDP per capita affect GER in Indonesia, both partially and simultaneously, especially in 2015-2019.

\section{METHODS}

The research method used in this study is quantitative in the form of descriptive and associative research. In this study, the analysis model used is a panel data regression model that combines cross-section and time-series data. In this study, the modified model used covers the use of a wider scope of research, which is carried out in one country. This is different from previous studies which only examined a certain city or district. The cross-section data used are 34 provinces in Indonesia which are combined using time series data from 2015 to 2019. This study aims to analyze factors such as poverty, the number of education units, student-to-teacher ratio, and per capita GRDP and its impact. on GER for a high school education or equivalent in Indonesia.

The variables used in this study include the independent variable and the dependent variable. The dependent variable used in this study is GER (Y). Meanwhile, the independent variable used includes poverty $\left(\mathrm{X}_{1}\right)$, the number of education units (schools) $\left(\mathrm{X}_{2}\right)$, the ratio of students and teachers $\left(\mathrm{X}_{3}\right)$, and per capita GRDP $\left(\mathrm{X}_{4}\right)$. The type of data used in this study is secondary data. Secondary data used in this study is in the form of panel data. Where the crosssection data here uses 34 provinces in Indonesia. While the time-series data used is 5 years, from 2015 to 2019. The secondary data used consists of GER data, the percentage of the poor (P0), the number of education units (schools) for high school education/equivalent, the number of teachers and students at high school education/equivalent, and per capita GRDP. The data used is sourced from the National Statistics Agency.

The data analysis technique used in this research is panel data regression that combines time series and individual data (cross-section). Panel data analysis in this study was carried out using the help of Microsoft Excel 2010 and Eviews 10 software. 
The panel data regression model in this study can be formulated as follows.

$\mathrm{APK}_{\text {it }}=\quad \beta 0+\beta 1 \mathrm{KMSKN}_{\mathrm{it}}+\beta 2 \mathrm{JSP}_{\mathrm{it}}+\beta 3 \mathrm{RSG}_{\mathrm{it}}+\beta 4 \mathrm{PDRB}_{\mathrm{it}}+\mathrm{e}_{\mathrm{it}}$

Where:

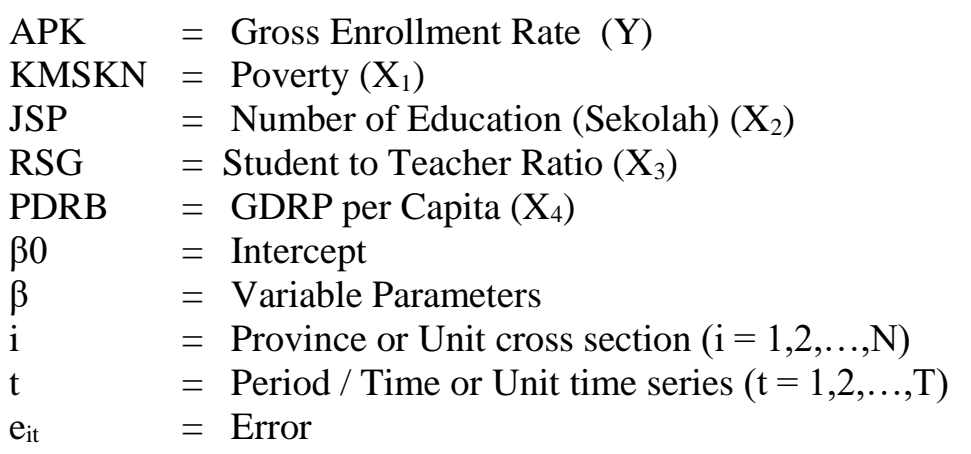

To analyze panel data, 3 (three) estimation models are used, namely the common effect model, the fixed-effect model, and the random effect model. Meanwhile, the model suitability test was carried out with 2 (two) tests consisting of the Chow test (F statistical test) and the Hausman test. In addition, in this study, a classic assumption test was also carried out in the form of a heteroscedasticity test and a multicollinearity test to see whether there was a problem or not in the regression model used. Hypothesis testing in this study was carried out using the $\mathrm{t}$-test and $\mathrm{F}$ test. Meanwhile, to predict how much the proportion or percentage of all independent variables together can explain the dependent variable, an analysis was carried out using the calculation of the coefficient of determination $\left(\mathrm{R}^{2}\right)$.

\section{RESULTS AND DISCUSSION}

Table 1. Descriptive Statistics

\begin{tabular}{lccccc}
\hline & APK & KMSN & JSP & RSG & PDRB \\
\hline Mean & 83.76382 & 10.97106 & 1043.700 & 13.79622 & 55731.67 \\
Maximum & 99.51000 & 28.40000 & 5884.000 & 20.39145 & 269074.0 \\
Minimum & 65.07000 & 3.420000 & 90.00000 & 8.612642 & 14867.00 \\
Observations & 170 & 170 & 170 & 170 & 170 \\
Cross sections & 34 & 34 & 34 & 34 & 34 \\
\hline
\end{tabular}

Source: Secondary Data, 2021 (processed)

Based on Table 1, it can be concluded that the highest GER for high school / equivalent education in Indonesia in 2015-2019 is East Kalimantan Province (2017) and the lowest is Papua Province (2018). The highest percentage of poor people (P0) in Indonesia in 2015-2019 was Papua Province (2015 and 2016) and the lowest was DKI Jakarta Province (2019). For the highest number of education units (schools) at the high school / equivalent level in 2015-2019, there were 5884 schools in West Java Province (2019) and the lowest was 90 schools in North Kalimantan Province (2015). The highest student-to-teacher ratio at the high school / equivalent level in Indonesia in 2015-2019 was 20.4 in West Java Province (2016) and the lowest was 8.6 in Aceh Province (2018). Meanwhile, the highest per capita GRDP in Indonesia in 2015-2019 was IDR 269,074,000 in DKI Province (2019) and the lowest was IDR 14,867,000 in East Nusa Tenggara Province (2015).

Based on the results of the model suitability test using the Chow test (F statistical test) and the Hausman test, the selected panel data regression model is the fixed effect model. In addition, the heteroscedasticity test shows that there is no heteroscedasticity problem. This is evidenced by the probability value of the poverty variable $\left(\mathrm{X}_{1}\right)(0.3460)$, the variable number of education units (school) $\left(\mathrm{X}_{2}\right)(0.0843)$, the student and teacher ratio variable $\left(\mathrm{X}_{3}\right)(0.1842)$, 
and the Product variable. Gross Regional Domestic (GRDP) per capita $\left(\mathrm{X}_{4}\right)(0.5279)>0.05$. Likewise, the multicollinearity test also shows that there is no multicollinearity problem in the regression model which is indicated by the correlation value between the independent variables all of which have a value of $<0.85$. The coefficient of determination (R2) also shows a value of 0.846045 or $84.60 \%$. This means that the percentage of the independent variables affecting the dependent variable is $84.60 \%$. Meanwhile, $15.40 \%$ was influenced by other variables which were not examined in this study. For more details, the panel data regression model using the fixed-effect model can be seen in Table 2 as follows. 
Table 2. Results of Panel Data Regression Model Fixed Effect

Dependent Variable: APK?

Method: Pooled Least Squares

Date: $02 / 11 / 21$ Time: $16: 46$

Sample: 20152019

Included observations: 5

Cross-sections included: 34

Total pool (balanced) observations: 170

\begin{tabular}{crrrl}
\hline Variable & Coefficient & Std. Error & t-Statistic & Prob. \\
C & 63.71366 & 11.95299 & 5.330352 & 0.0000 \\
KMSN? & -1.141650 & 0.441607 & -2.585219 & 0.0108 \\
JSP? & 0.005408 & 0.003671 & 1.473137 & 0.1431 \\
RSG? & 1.583412 & 0.581625 & 2.722396 & 0.0074 \\
PDRB? & $9.13 \mathrm{E}-08$ & $3.92 \mathrm{E}-08$ & 2.325062 & 0.0216
\end{tabular}

Fixed Effects (Cross)

_ACEH--C 18.89846

_SUMUT--C $\quad-5.120017$

_SUMBAR--C $\quad 3.305359$

_RIAU--C $\quad-8.910924$

JAMBI--C $\quad-1.814436$

SUMSEL-C $\quad-2.355057$

_BENGKULU--C $\quad 18.00493$

_LAMPUNG--C $\quad 0.878908$

BABEL-C $\quad-6.500604$

_KEPRI--C $\quad 0.037048$

JAKARTA--C $\quad-38.76290$

JABAR--C $\quad-44.46149$

JATENG--C $\quad-11.36708$

_YOGYAKARTA--C $\quad 14.15529$

_JATIM--C $\quad-27.43333$

_BANTEN-C $\quad-28.23056$

_BALI--C $\quad-3.508612$

_NTB--C 20.36231

_NTT--C 12.91167

_KALBAR--C $\quad-5.976164$

_KALTENG--C $\quad-6.754091$

_KALSEL--C $\quad-10.19064$

_KALTIM--C $\quad-3.793493$

_KALUT--C 2.693465

_SULUT--C 4.501229

_SULTENG--C $\quad 8.953888$

_SULSEL--C $\quad-4.696279$

_SULTRA--C $\quad 7.387512$

GORONTALO-C $\quad 17.04201$

_SULBAR--C 8.259007

_MALUKU--C 27.19683

_MALUT--C $\quad 9.997050$

_PAPBAR--C 27.07957

_PAPUA--C 8.211141

Effects Specification

Cross-section fixed (dummy variables)

R-squared
Adjusted R-squared

0.846045 Mean dependent var

83.76382

0.802891 S.D. dependent var

6.757932

S.E. of regression

3.000315 Akaike info criterion

5.229374

Sum squared resid

1188.249 Schwarz criterion

5.930317

Log-likelihood

-406.4968 Hannan-Quinn criter.

5.513808

F-statistic

19.60525 Durbin-Watson stat

2.218310

Prob(F-statistic) 0.000000

Source: Processed Results Eviews 10, 2021 
Based on Table 2, it can be seen that the results of hypothesis testing are partially ( $t$ test) or simultaneously ( $F$ test). The results of partial hypothesis testing above can be concluded that the variable poverty $\left(\mathrm{X}_{1}\right)$, Student to Teacher Ratio $\left(\mathrm{X}_{3}\right)$, and GRDP per capita $\left(\mathrm{X}_{4}\right)$ have a significant effect on GER. While the variable number of education units (school) $\left(\mathrm{X}_{2}\right)$ does not affect GER. While simultaneously it can be concluded that there is a significant influence between the poverty variable $\left(X_{1}\right)$, the number of education units (schools) $\left(X_{2}\right)$, the ratio of students and teachers $\left(\mathrm{X}_{3}\right)$, and the GDP per capita $\left(\mathrm{X}_{4}\right)$ simultaneously on GER. The summary of the results of the t-test (partial test) and $\mathrm{F}$ test (simultaneous test) based on Table 2 can be seen in the table below.

Table 3. Result of T-Test (Partial Test) and F Test (Simultaneous Test)

\begin{tabular}{|c|c|c|c|}
\hline Independent Variable & $\begin{array}{c}\text { Dependent } \\
\text { Variable }\end{array}$ & Probability & Conclusion \\
\hline Poverty & GER & 0.0108 & $\begin{array}{l}\text { Hypothesis is } \\
\text { Accepted }\end{array}$ \\
\hline $\begin{array}{l}\text { Number of Education Units } \\
\text { (School) }\end{array}$ & GER & 0.1431 & $\begin{array}{l}\text { Hypothesis is } \\
\text { Rejected }\end{array}$ \\
\hline Student to Teacher Ratio & GER & 0.0074 & $\begin{array}{c}\text { Hypothesis is } \\
\text { Accepted }\end{array}$ \\
\hline GRDP Per Capita & GER & 0.0216 & $\begin{array}{c}\text { Hypothesis is } \\
\text { Accepted }\end{array}$ \\
\hline $\begin{array}{c}\text { Poverty, Number of } \\
\text { Education Units (School), } \\
\text { Student to Teacher Ratio, and } \\
\text { GRDP Per Capita }\end{array}$ & GER & 0.000000 & $\begin{array}{l}\text { Hypothesis is } \\
\text { Accepted }\end{array}$ \\
\hline
\end{tabular}

Source: Processed Results Eviews 10, 2021

The discussion of this research is:

\section{Effect of Poverty $\left(\mathrm{X}_{1}\right)$ on GER (Y)}

Poverty is one of the factors that most influence educational participation in an area. In the theory of the vicious cycle of poverty (Vicious Cycle of Poverty) which was initiated by Nurkse, he states that "a poor country is poor because it is poor" (a poor country is poor because he is poor). This theory can be intended that the background for the occurrence of poverty is market imperfection, underdevelopment, and underdevelopment which will impact on low productivity. Low productivity will have an impact on the low income received. So that it will automatically lead to low savings and investment which has an impact on underdevelopment and underdevelopment. Backwardness and backwardness are closely related to the low level of education a person has. Low education will cause a person to lack the ability and skills so that they cannot maximize the potential of existing resources. This inability will ultimately lead to low productivity. The community becomes unable to increase their income, which leads to low savings and investment. This in turn will impact the low ability of the community to invest in education.

Based on the analysis, it was found that the coefficient value of the poverty variable $\left(\mathrm{X}_{1}\right)$ was -1.141650 and had a significant effect on APK which was indicated by the value of Probability $<0.05$ or $0.0108<0.05$. A negative coefficient means that there is a negative relationship between poverty and GER. This explains that the higher the poverty rate, the lower the GER percentage will be. The results of the analysis are also following the data obtained from the National BPS, where during the 2015-2019 period the percentage of poverty in each province in Indonesia continued to experience a significant decline. The decrease in the 
percentage of poverty was also followed by an increase in the percentage of GER in each province in Indonesia. The results of this study are in line with the results of research conducted by (Karini, 2018) which states that increasing SER can reduce poverty levels. In addition, (Khairunnisa et, 2014) found that in addition to increasing the education budget, reducing the poverty rate must also be done to support increased school participation.

\section{Effect of Number of Education Units (School) ( $\left.\mathbf{X}_{2}\right)$ on GER (Y)}

School is an important component so that the learning process can take place well. The minimal number of schools can hinder the increase in educational participation in an area due to the limited capacity, which causes many school-age children not to enroll in school. This of course results in an increase in dropout rates and a low GER. Based on the results of the analysis, the coefficient value of the number of education units (schools) variable $\left(\mathrm{X}_{2}\right)$ is 0.005408 and does not have a significant effect on GER as indicated by the probability value $>0.05$ or $0.1431>0.05$. Although the results of the analysis are not following the data obtained from the National BPS, this does not mean that schools have no role at all in increasing GER. This indicates that a large number of registered schools is not used as effectively as possible so that it cannot absorb students as expected which results in a decrease in the percentage of GER. The results of this study contradict the results of research conducted by (Rahmatin dan Soejoto, 2017) which found that the number of schools had a significant effect on SER. In fact, (Moyi, 2011) study also revealed that the problem of postponing school enrollment should be overcome by increasing the number of schools close to the community.

\section{The Effect of Student and Teacher Ratio ( $\left.\mathrm{X}_{3}\right)$ on GER (Y)}

The ratio between the number of students being taught to teachers who teach is one of the problems that are even directly regulated in the Government Regulation of the Republic of Indonesian Number 74 Article 12 Paragraph (1) of 2008 concerning teachers. One of the government's goals to regulate this is so that the learning process in the classroom runs effectively. Based on the analysis, it was found that the student-teacher ratio variable coefficient $\left(\mathrm{X}_{3}\right)$ was 1.583412 and had a significant effect on GER as indicated by the probability value $<0.05$ or $0.0074<0.05$. The positive coefficient illustrates that there is a positive relationship between the ratio of students and teachers to GER. However, this does not mean that the higher the ratio of students to teachers will increase the GER, but it will explain more to the availability of an adequate number of teachers so that it will be able to increase school capacity. By increasing the capacity of schools, it will help in increasing the GER. The results of this study are similar to the results of research conducted by (Listianawati, 2012) who found that the student-teacher ratio affects the APS for SMP level. (Purwanto, 2010) in his research also found that the student-teacher ratio has a significant effect on the level of educational participation for all school levels.

\section{The Effect of PDRB Per Capita $\left(\mathbf{X}_{4}\right)$ on GER (Y)}

GRDP per capita is an indicator that can be used to see the level of community welfare in an area. The greater the per capita GRDP received by a person, the better his standard of living and welfare will be. The increase in welfare certainly has an impact on a person's decision to continue his education. Based on the results of the analysis, the coefficient value of the per capita GRDP variable $\left(\mathrm{X}_{4}\right)$ is $9.13 \mathrm{E}-08$ and has a significant effect on GER as indicated by Probability $<0.05$ or $0.0216<0.05$. A positive coefficient indicates that the greater the per capita GRDP received by a person, the more the percentage of GER will be increased. This indicates that the higher income a person receives will indirectly have an impact on a person's tendency to improve his education. The results of this study are in line with the results of the research found by (Jolianis, 2015) who found that there was a significant effect of per capita income on the achievement of school participation. Other findings were also expressed by 
(Zhao dan Glewwe 2011) in their study which revealed that per capita income will help increase school participation.

The Influence of Poverty ( $\left.\mathrm{X}_{1}\right)$, Number of Education Units (Schools) $\left(\mathrm{X}_{2}\right)$, Student and Teacher Ratio ( $\left.\mathrm{X}_{3}\right)$, and GRDP Per Capita $\left(\mathrm{X}_{4}\right)$ on GER (Y)

After partially testing each of these factors, the researcher then tries to test the hypothesis simultaneously to see how the effects of these factors are tested together on GER. Based on the analysis results obtained from testing the hypothesis using the F test, it can be concluded that there is a significant influence between poverty $\left(\mathrm{X}_{1}\right)$, the number of education units (schools) $\left(\mathrm{X}_{2}\right)$, the ratio of students and teachers $\left(\mathrm{X}_{3}\right)$, and GRDP per capita $\left(\mathrm{X}_{4}\right)$ simultaneously to GER (Y). Where the results of statistical analysis with the F test show the probability value (F-statistic) $<0.05$ or $0.000000<0.05$. This means, if the percentage of poverty continues to decline every year which is then balanced by the addition and distribution of the number of education units (schools), achieving the ideal student-teacher ratio and increasing per capita GRDP received by each individual, then this can help. increase the percentage of the GER.

\section{CONCLUSION}

Based on the data that has been collected and carried out a series of tests, it can be concluded that, first, there is a significant influence between poverty and the GER for high school education level or equivalent in Indonesia in 2015-2019. Second, there is no significant effect between the number of education units (schools) on the GER for high school education level or equivalent in Indonesia in 2015-2019. Third, there is a significant influence between the ratio of students and teachers to the GER for high school education level or equivalent in Indonesia in 2015-2019. Fourth, there is a significant influence between GDP per capita on the GER for high school education level or equivalent in Indonesia in 2015-2019. Fifth, there is a significant influence between poverty, the number of education units (schools), student-toteacher ratios, and GRDP per capita simultaneously on GER.

The results of the research above have different results from those conducted by (Nielson, 2014). Where in the results of the study above the number of educational units (schools) does not have a significant effect on the Gross Enrollment Rate (GER), while according to a study conducted by (Nielson, 2014)in America, it was found that there was an effect of school construction on the level of school participation that was high. marked by an increase in the number of student enrollment indicators. 


\section{REFERENCE}

Peraturan pemerintah republik Indonesia nomor 74 tahun 2008, (2008).

Istiqomah et al. (2018). Analisis partisipasi pendidikan pada masyarakat miskin dusun gumuk limo desa nogosari kecamatan rambipuji kabupaten jember. Jurnal Pendidikan Ekonomi, 12(2), 227-235. https://doi.org/10.19184/jpe.v12i2.8553

Jolianis. (2015). Pengaruh alokasi anggaran sektor pendidikan, pendapatan perkapita dan pendidikan kepala rumah tangga terhadap angka partisipasi sekolah di Kabupaten/Kota Provinsi Sumatera Barat. Journal of Economics and Economics Education, 3(2), 169184. https://doi.org/10.22202/economica.2015.v3.i2.254

Jonaidi, A. (2012). Bahan mendeley analisis pertumbuhan ekonomi dan kemiskinan. Kajian Ekonomi, 1(1), 140-164.

Karini, P. (2018). Pengaruh tingkat kemiskinan terhadap angka partisipasi sekolah usia 16-18 tahun di Provinsi Kepulauan Bangka Belitung. Al-Ishlah: Jurnal Pendidikan, 10(1), 103115. https://doi.org/10.35445/alishlah.v10i1.64

Khairunnisa, K., Hartoyo, S., \& Anggraeni, L. (2014). Determinan angka partisipasi sekolah SMP di Jawa Barat. Jurnal Ekonomi Dan Pembangunan Indonesia, 15(1), 91. https://doi.org/10.21002/jepi.v15i1.444

Listianawati, I. (2012). Faktor-faktor yang mempengaruhi pendidikan dasar di Sulawesi Utara. Institut Pertanian Bogor.

Moyi, P. (2010). Household characteristics and delayed school enrollment in Malawi. International Journal of Educational Development, 30(3), 236-242. https://doi.org/10.1016/j.ijedudev.2009.11.008

Nielson. (2014). The Effect of School Construction on Test Scores, School Enrollment, and Home Prices. Journal of Public Economics, 120, 18-31. https://doi.org/http://dx.doi.org/10.1016/j.jpubeco.2014.08.002

Pramudibyanto, H., \& Weningsih, S. (2018). Keterlibatan tutor dalam peningkatan angka partisipasi kasar (Apk) mahasiswa (Studi di universitas terbuka upbjj Semarang). Maksimum, 9(1), 11. https://doi.org/10.26714/mki.8.3.2018.11-21

Purwanto, D. A. (2010). Decentralization and its impact on the primary. Journal of Indonesian Economy and Business, 25(1), 41-58. https://doi.org/10.22146/jieb.6302

Rahmatin, U.Z.,\& Soejoto, A. (2017). Pengaruh tingkat kemiskinan dan jumlah sekolah terhadap angka partisipasi sekolah (APS) di Kota Surabaya. Jurnal Pendidikan Ekonomi Manajemen Dan Keuangan, 01(02), 127-140. https://doi.org/10.26740/jpeka.v1n2.p127140

Ustama, D. D. (2009). Peranan pendidikan dalam pengentasan kemiskinan. Dialogue, 6(1), 112.

Zhao Meng, M., \& Glewwe Paul, P. (2010). What determines basic school attainment in developing countries? Evidence from rural China. Economics of Education Review, 29(3), 451-460. https://doi.org/10.1016/j.econedurev.2009.10.008 